\title{
炭化ケイ素の焼結に及ぼすメカノケミカル効果
}

\author{
管 野善 則 \\ （名古屋工業技術試験所）
}

\section{Mechanochemical Effect on the Sintering Behavior of Silicon Carbide Powder}

\author{
Yoshinori KANNO \\ Government Industrial Research Institute, Nagoya
}

Aluminium-doped beta silicon carbide powders were activated mechano-chemically by fine grinding in a vibration ball mill. The resultant powders doped with metallic boron (0.2\%) and carbon (2\%) was normally sintered under Argon flow, and the effect of mechanochemical activation on the densification of $\beta-S i C$ was investigated. The results obtained are as follows :

(1) The moldability of the ground powders decreased remarkably. The mechanochemical activation made very little contribution to the densification of $\beta-\mathrm{SiC}$ and accelerated only the surface diffusion at lower temperatures.

(2) Fine powders with the average particle size of $0.29 \mu \mathrm{m}$ and maximum size of ca. $1.0 \mu \mathrm{m}$ is recommended as a starting powder.

(3) The ground powders showed a large weight loss during sintering, and stimulated the growth of plate-like crystals at elevated sintering temperatures. The plate-like crystals tend to retard the extensive consolidification of $\beta$-SiC.

[Received May 1, 1986]

Key-words : Silicon carbide, Vibration ball milling, Activation of ceramic powders, Surface diffusion, $B_{4} C / C$ thermocouple, Normal sintering, Boron, Carbon

\section{1. 緒 言}

共有結合性化合物からなるセラミックスは，その結合 の特質からみて高温構造材料, 高温機能材料としての用 途が考えられ，炭化ケイ素 $(\mathrm{SiC})$, 窒化ケイ素 $\left(\mathrm{Si}_{3} \mathrm{~N}_{4}\right)$ を代表例として盛んに研究開発されている. しかし，こ れらの結晶は結合に方向性があり金属材料之異なり，2 物体間の接触界面における電子雲の変形や緩和が起こり 難く,単味での常圧焼結ではち密化が困難とされている.

$\mathrm{SiC}$ においては, Prochazka ${ }^{1}$ が $\beta$ 型の微粉末に炭素 (C) とホウ素 (B) を助剤として添加することにより 常圧焼結による固相焼結に成功していらい急速に発展 し，より高密度で高温強度の低下しない焼結体をめざし て助剂探索や焼結手法の改良が行われている2) 4).

著者は焼結原料粉末の “活性” の観点から研究を進め ているが，従来より粉体材料の特性，活性を記述する方 法として，熱量計を用いて表面自由エネルギーの測定よ り表面過剩エンタルピー $\Delta H^{*}$ を算出する熱力学法と X 線回折のピーク強度の低下や，ピーク幅の広がりから格 子ひずみなに゙を算出する結晶学法とが一般に用いられて いる. 更に赤外線吸収スペクトルやラマン分光法により， シグナルのシフトを観測し，結晶中の結合状態 (Bond

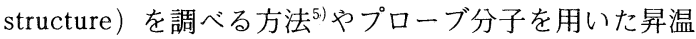
脱離法により表面活性を探る手法 ${ }^{6}$ が考えられている。

しかしこれらの手法により評価されてきた粉体材料の
特性，活性と易焼結性，ち密化能との関係が明白にされ ているとは言い難いのが現状と思われる．著者は前報》 において，焼結特性向上をめざした振動ボールミルによ る $\mathrm{SiC}$ 粉末のハンドリングに関してメカノケミカル効 果の観点から論じ，粉末特性，活性の変化を比表面積測 定，X 線回折，熱量計，昇温脱離法により検討し，以 下の点を明らかにした。 (1)微粉砕処理により粉末の比表 面積は著しく増大し, 表面の活性化度, 結晶格子のひず みも増大する。(2)粉砕された $\mathrm{SiC}$ 粉末の表面拡散は著 しく助長されるが，しかし誘起された大幅な格子ひずみ の増大はアニーリングにより緩和されてしまう傾向にあ る.

しかしながら，これらのメカノケミカル効果が最終的 な焼結によるち密化効果に対して，いかに作用するかに 関しては明らかにされていない。そこで本研究では $\mathrm{SiC}$ 粉末の焼結に及ぼすメカノケミカル効果に関して 結論を明らかにすることを目的として行った。

\section{2. 実 験}

\section{1 原料}

使用した $\mathrm{SiC}$ 粉末はイビデン製で，製造時アルミニ ウム $(\mathrm{Al})$ をドープした「ベーターランダムウルトラファ イン」である。 その粉末特性を表 1 に記した。各特性值 の測定法の詳細は前報7の実験の項に記した．表 1 の格 
Table 1. Characteristics of Al-doped $\beta$-SiC powders.

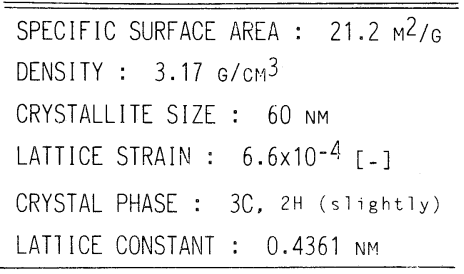

子定数 $a_{0}$ は他の $\mathrm{Al}$ をドープしていない「ウルトラファ イン $\beta$ - $\mathrm{SiC} 」$ の值 $0.4359 \mathrm{~nm}$ (前報7で使用した粉末) と比較して膨張しており, Al が固溶した可能性を示し ている。ちなみに $\mathrm{Al}$ ，ケイ素，Cの共有結合半径は， それぞれ $0.125 \mathrm{~nm}, 0.12 \mathrm{~nm}, 0.077 \mathrm{~nm}$ であり ${ }^{81}$ ，格子 定数の膨張を裏付けるものと考えられる.

更に， $0.3 \%$ のへキサメタリン酸ナトリウム水溶液中 に超音波を用いて十分に分散させ，セイシン企業製 SKA-5000により粒度分布を測定し，図 1 に示す。その 結果, 本試料は平均粒径が $0.29 \mu \mathrm{m}$ で， $1 \mu \mathrm{m}$ 以下の粒 子含有率が $96 \%$ であり，比較的粒度調整の良い粉末で あった。

表 2 に本原料中に含有される金属不純物の化学分析結 果を記した。化学分析の方法は以下のようである. $\mathrm{Na}_{2} \mathrm{CO}_{3}$ 溶融後, 融解物を $\mathrm{HCl}$ に溶解し, 更に不溶性 $\mathrm{SiO}_{2}$ を沪過し，その不溶 $\mathrm{SiO}_{2}$ に $\mathrm{HF}-\mathrm{H}_{2} \mathrm{SO}_{4}$ を添加し 加水分解し, $\mathrm{Si}$ を $\mathrm{SiF}_{4}$ として揮発させる. そののち, この残液と沃液を混ぜて ICP 発光分析，原子吸光分析

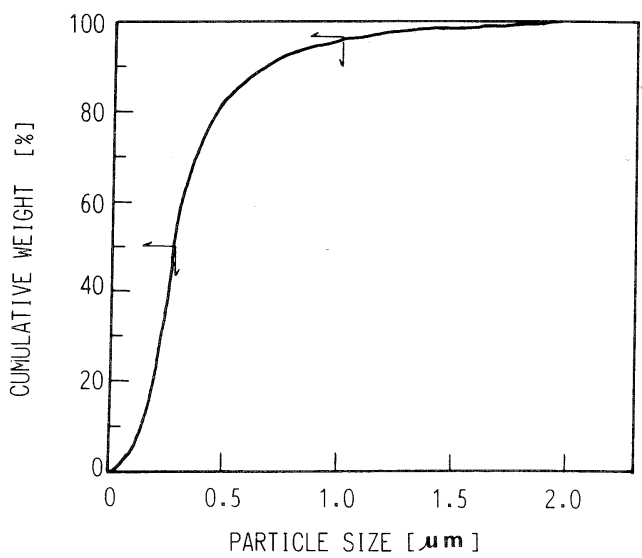

Fig. 1. Particle size distribution of as-received Aldoped $\beta$-SiC powders.

Table 2. Chemical analysis of metal impurity in Aldoped $\beta$-SiC.

\begin{tabular}{rrrrrrrrrrr}
\hline \hline Al & $\mathrm{Ca}_{2}$ & $\mathrm{Cu}_{4}$ & $\mathrm{Ti}$ & $\mathrm{Mg}$ & $\mathrm{Mn}$ & $\mathrm{Cr}$ & $\mathrm{Fe}$ & $\mathrm{Ni}$ & $\mathrm{B}$ \\
6300 & 510 & 13 & 260 & 150 & 10 & 340 & 630 & 7 & 8 \\
& & & & & & & & UNIT & (PPM) \\
\hline
\end{tabular}

に供した。

表 2 に記した $\mathrm{Al}$ の含有量は前報》で使用した試料の $\mathrm{Al}$ の含有量, 約 $340 \mathrm{ppm}$ と比較して 19 倍近い值を示し た.

添加剤として用いたホウ素はStarck 製の無定形金属 ホウ素粉末（純度 95９7\%）であり，炭素としては有 機樹脂を炭化した無定形の微細粉末を使用した。

\section{$2.2 \mathrm{SiC}$ の粉砕及び混合粉末の成形}

$\mathrm{Al}$ ドープした $\beta$ - SiC 粉末を精製メ夕ノール中による 湿式法で振動ボールミル粉砕し, メカノケミカル活性化 処理を施した。湿式法で行った理由は酸素混入防止及び 均一粉砕を達成させるためである。使用したボール及び ポットは $\mathrm{SiC}$ 製のものを使用し，不純物の混入を極力 抑制した。なお，粉砕実験の詳細は前報”に記した。粉 砕された $\beta-\mathrm{SiC}$ は室温下で真空脱気し, 窒素中に保存 し，混合・成形処理に供した。

粉末の混合は所定量の B と C を添加し，アセトンを 媒体としてテフロン製のボールを用い，24時間処理し た. 混合粉末は $0.5 \mathrm{~g}$ ひょう量し, $88 \mathrm{MPa}$ で予備成形 したのち，ラバーに真空充てんし，196 MPa の静水圧

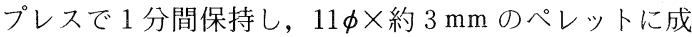
形した。得られた成形体はノギス，マイクロメーターに より，その寸法を測定し成形体密度を算出した。

\section{3 焼結及び焼結体の特性評価}

焼結は黒鉛抵抗炉により $\mathrm{B}_{4} \mathrm{C} / \mathrm{C}$ サーモカップルを用

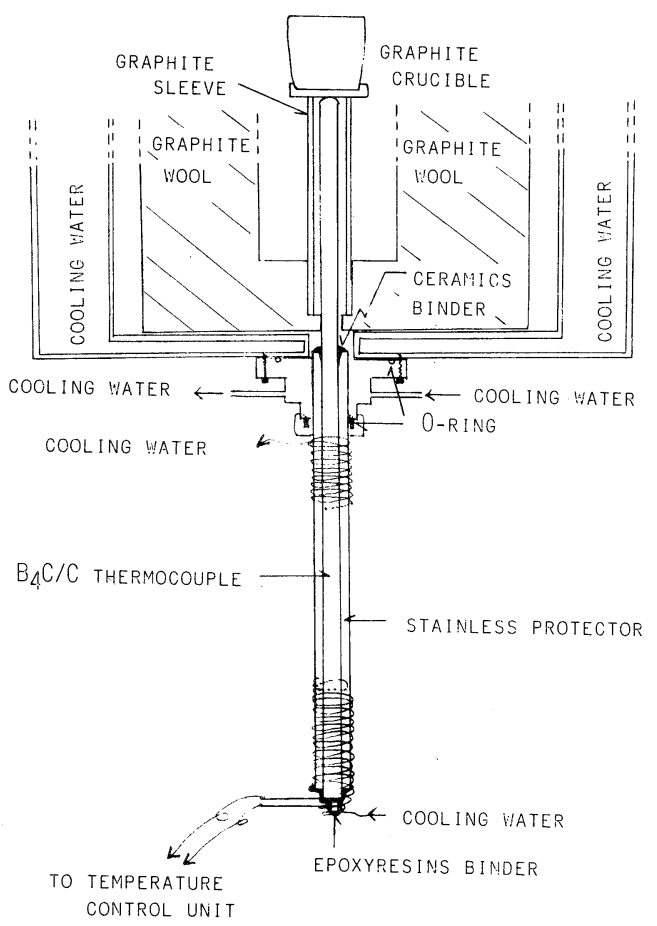

Fig. 2. Details of attachment on $\mathrm{B}_{4} \mathrm{C} / \mathrm{C}$ thermocouple. 
いて炬内温度を P.I. D. 制御し, 焼結温度（保持温度） は親空よりパイロスコープで測定した。常温から $1600^{\circ} \mathrm{C}$ までの昇温中は昇温速度約 $300^{\circ} \mathrm{C} / \mathrm{h}$ で油拡散ポ ンプで排気しながら真空中で加熱した。 そののち, $1600^{\circ} \mathrm{C}$ で 15 分間保持し，その間にアルゴンガス 1 気圧 を導入し, 更に同じ昇温速度で所定の焼結温度まで昇温 し，同温度で 15 分間焼成した。

$\mathrm{B}_{4} \mathrm{C} / \mathrm{C}$ サーモカップルの詳細及び温度制御ユニット の細部は前報 ${ }^{7)}$ に記した。本論文では，図 2 にこのサー モカップルの真空炉に対する装着法に関して詳しく示し た. $\mathrm{B}_{4} \mathrm{C} / \mathrm{C}$ サーモカップルは外側がグラファイトでお おわれており，ち密性からみてこのまま真空炬に装着す ることは不可能である. したがって, 本実験ではステン レス保護管中に装てんし，加熱部近傍端は無機系接着剤 で固定し，冷接点を重ねた水冷端はエポキシ系接着剤で 固定し，真空に保った。その結果，室温下で短時間の内 に $10^{-4} \mathrm{~Pa}$ 台に入り, $2200^{\circ} \mathrm{C}$ までの真空あるいは不活性 ガス中焼結が可能であった。

得られた焼結体の密度は水中置換によるアルキメデス 法により測定した．焼結体の破断面を走查型電子顕微鏡 (SEM) により観察し，その組織を調べた。

\section{3. 結果及び考察}

\section{1 成形体密度に及ぼす粉砕の効果}

$\mathrm{SiC}$ のような難焼結性化合物の焼結においては成形 体密度をいかに上げるかは非常に重要な問題と考えられ る. 図 3 に粉砕時間による成形体密度の変化の様子を示 した。成形体の相対密度は粉砕時間の増大につれて徐々 に低下する傾向を示し, 特に長時間の粉砕処理は成形体 密度の著しい低下につながり，あまり好ましくない。

長時間粉砕による著しい成形体密度の低下は $\mathrm{SiC}$ に おいて特に著しいものと考えられ，定性的には以下のよ うに推論される．著者はすでに振動ボールミル処理によ る $\mathrm{SiC}, \mathrm{Si}_{3} \mathrm{~N}_{4}, \mathrm{SiO}_{2}$ (石英) 粉末の特性変化について 報告した ${ }^{10)}$. その結果, $\mathrm{SiC}$ は $\mathrm{Si}_{3} \mathrm{~N}_{4}$ と比較して, より

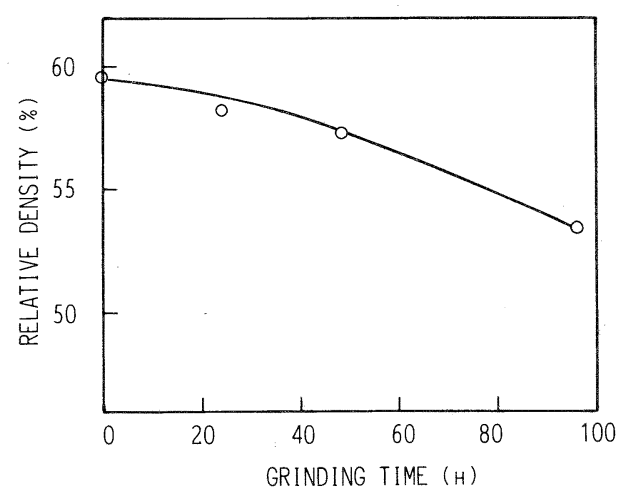

Fig. 3. Variation of relative density with grinding time.
微細粒子にまで粉砕されやすく，格子ひずみも大きく， またひずみが残留しやすい傾向があることを明らかにし た.その原因としては， $\mathrm{SiC}$ 粒子の場合，振動ボール ミルによるせん断応力により破壊が起こり, 更に靶性值 の低さも手伝って破壊の伝ぱが進行しやすく，相対的に 破断面に鋭利な面が発生しやすい。 その結果，成形性の 低下に結びつくものと考えられる.

\section{2 焼結体密度に及ぼす粉砕の効果}

田中ら ${ }^{11}$ は $\beta-\mathrm{SiC}$ 粉末の常圧焼結における $\mathrm{B} と \mathrm{C}$ の 最適添加量に関する研究で，焼結に必要な $\mathrm{B}$ の最適添 加量は $0.15 \sim 0.2 \mathrm{wt} \%$ であり，0.3\% 以上添加すると 異常粒成長を起こし，C の最適量は 1 2 wt \% であるこ とを報告した。したがって本実験においては B，Cの 添加量をそれぞれ，特に記さないかぎり $0.2,2 \mathrm{wt} \%$ に 固定し，粉砕によるメカノケミカル効果が焼結過程にお けるち密化に対していかに作用するかを把握することに つとめた。

図 4 に粉砕時間による焼結体密度の変化を $2150^{\circ} \mathrm{C}$, $2000^{\circ} \mathrm{C}$ 焼成の場合について示す．ち密化の進行した $2150^{\circ} \mathrm{C}$ 焼成の場合，粉砕時間の増大につれて単調に焼 結体密度の低下がみられた。 $2000^{\circ} \mathrm{C}$ 焼成の場合も，96 時間粉砕した試料において著しくち密化が抑制されてお り，本実験条件下では強制的な振動ボールミル粉砕によ り粉末内部に格子ひずみの形で蓄積された機械的エネル ギ一の付与分は原料粉末のち密化能向上に対しては何ら 正の効果を及ぼすことがないと考えられる.

\section{3 焼結温度による焼結体密度の变化}

図 5 に焼結温度による焼結体密度の変化を未処理の粉 末と 96 時間粉砕処理した粉末の例について示す.

焼結体密度は $2100^{\circ} \mathrm{C}$ 付近で最大值を示し，それ以上 の温度域では徐々に低下する傾向を示している。これは 到達でき得る最高密度に達した後，焼結体内部に取り残

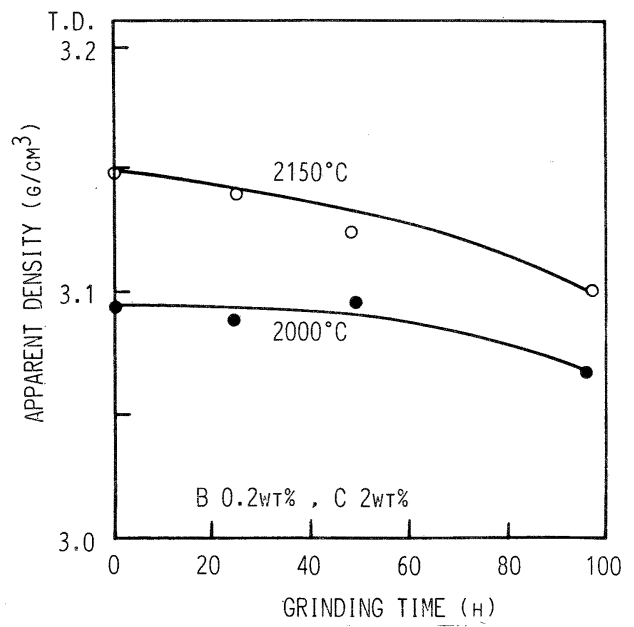

Fig. 4. Variation of apparent density of sintered bodies with grinding time. 


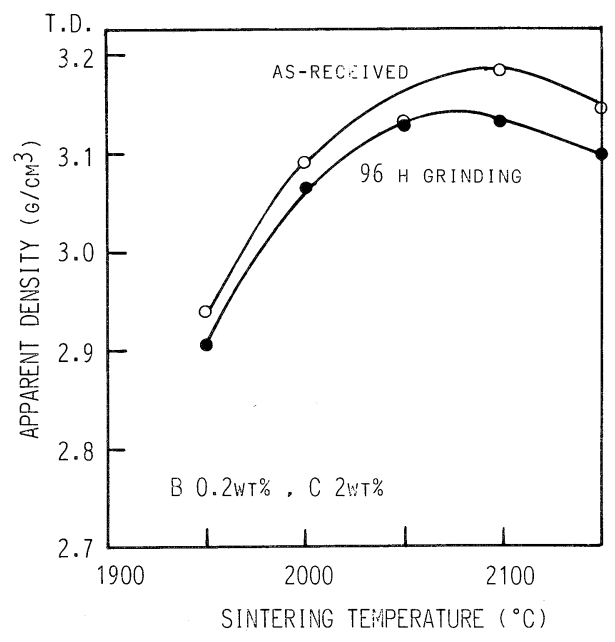

Fig. 5. Apparent density of sintered bodies as a function of sintering temperature.

された気孔をそれ以上に減ずることは困難であり，余剩 の熱エネルギーの投与は $\mathrm{SiC}$ の分解や異常粒成長のた めのエネルギーとして消費されてしまう結果, 逆に密度 の低下が生じるものと推量される．したがって $\mathrm{SiC}$ の ような強い共有結合性をもつ化合物の焼結においては, その温度, 添加物量, 雾囲気等に関する一連の最適焼結 条件が非常に狭い範囲に限定されてしまうものかもしれ ない.その理由としては概念的に Bond structure が挙 げられよう. Si と C は 2 種の電気陰性度の差が小さく, 結合の極性が微小亡なり，種々の意味での反応性が低下 している. また原子間の結合の方向性がきつく, 結合工 ネルギーも大きい，そのため，ある臨界温度になるまで 原子のゆらぎが小さく, 焼結を促すところまでいかない. また，その臨界温度を過ぎると急激に昇華・分解と結び ついてしまうものと考えられる.

大河内ら ${ }^{12)}$ はガス蒸発法で作製した $\mathrm{SiC}$ 超微粉体の 常圧焼結において, $2200^{\circ} \mathrm{C}$ で焼結したとき最高密度が 得られると報告している。本実験で $2100^{\circ} \mathrm{C}$ 近辺におい て最高密度を示した理由は粉末合成時における微量の $\mathrm{Al}$ の添加が結合のイオン性を増大させ, より低温にお ける焼結を可能ならしめたものと考えられる.

図 5 においても未処理粉末の方がち密化能が高く, 振 動ボールミルによる強制的な微粉砕処理は, 高密度焼結 体作製を目的とした粉末処理としてはあまり好ましくな いという結論が得られた。

\section{4 焼成時における質量損失に及ぼす粉砕の効果}

図 6 に $2000^{\circ}, 2100^{\circ} \mathrm{C}$ 焼成の場合について, 焼成に伴 う質量損失に及ぼす粉砕の効果を示した。粉砕時間の増 大につれて, 質量損失は激しくなる傾向にあり, 特に低 温焼結においては, 未処理と粉砕処理の差が大きく, 強 制的な微粉砕により結晶構造そのものが損傷を受け, 表

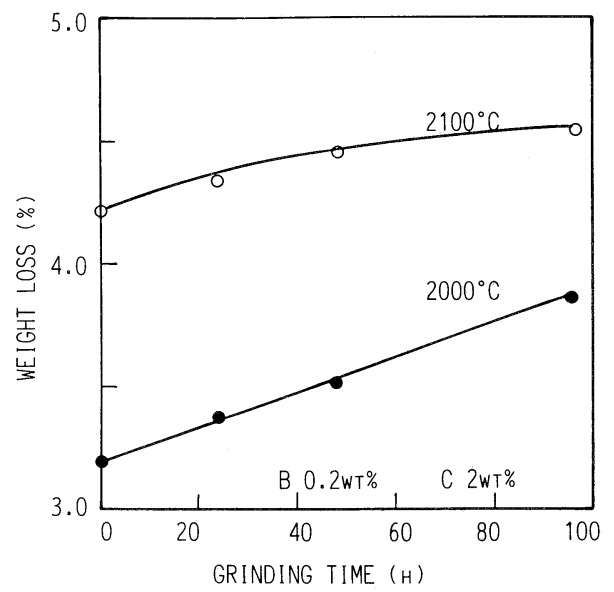

Fig.6. Variation of weight loss with grinding time.

面層近傍では比較的低温でも Si と C の結合が切れやす くなっている可能性がある. 更に粉末のハンドリングの 段階において，ぼうしても酸素の混入は避け難く, 酸素 含有量の増加も質量損失を大きくさせる原因とみられ る。

\section{5 焼結体密度に及ぼすカーボン添加量の効果}

従来より助剤としての B， C の効果として, Prochazka $^{1)}$ は B が粒界エネルギー $\left(\gamma_{\mathrm{gb}}\right)$ を下げ，C は 表面エネルギー $\left(\gamma_{\mathrm{sv}}\right)$ を上げ， $\gamma_{\mathrm{gb}} / \gamma_{\mathrm{sv}}<\sqrt{3}$ のときち密 化が可能になるとした．長谷ら ${ }^{13)}$ は $\gamma_{\mathrm{gb}} / \gamma_{\mathrm{sv}}=1.39$ が最 頻值であるとし， $\mathrm{SiC}$ のち密化にとって熱力学的制限 は存在しないとした。猪股ら ${ }^{14)}$ は $\gamma_{\mathrm{gb}}$ の平均值は $\gamma_{\mathrm{sv}}$ の 1.88 倍以上であろうと推論した。 Greskovich ら ${ }^{15)}$ は $\mathrm{B}$ が焼結時に表面拡散を抑え，粒成長を防止することに よってち密化すると考えた。これらの不一致性からみて B， C の添加効果に関して十分に解明されたとは言い難 いが，やはりCの焼結促進作用の一つは表面酸化物の

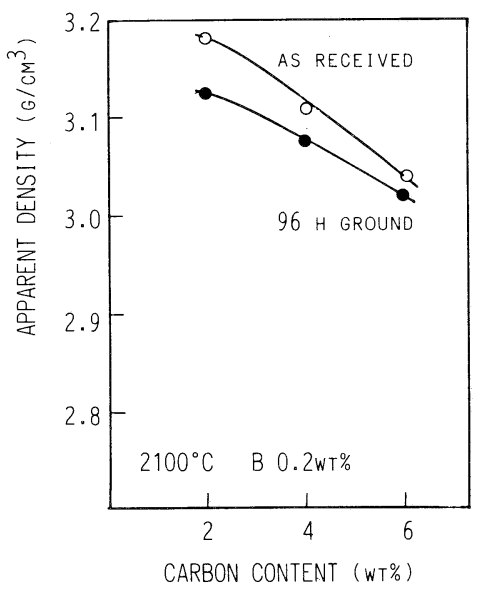

Fig. 7. Apparent density of sintered bodies as a function of the amount of carbon addition. 
除去による表面エネルギーの増大が挙げられる。

3.4 節に記したように粉哗試料は混入酸素量が未処理 のものと比較して増加している可能性が考えられるの
で，C添加量を変えたときの焼結体密度に及ぼす効果 を図 7 に示した，この場合，焼結温度は $2100^{\circ} \mathrm{C}$ ，添加 B 量 0.2 wt \% に固定して行った.

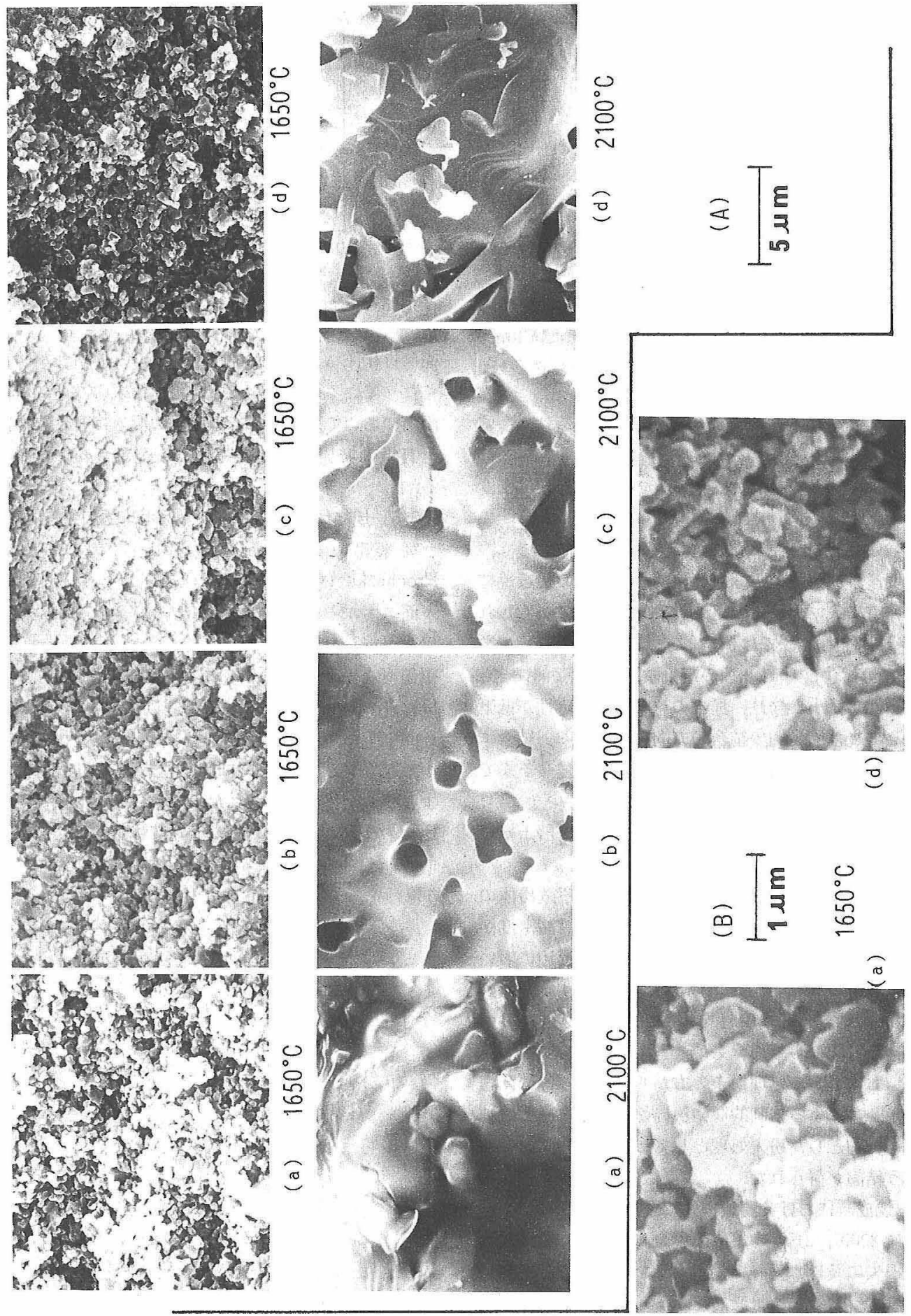

Fig. 8. SEM photographs of fracture surface of sintered bodies. Boron 0.2 wt $\%$, carbon 2 wt $\%$. (a) Original, (b) $24 \mathrm{~h}$ grinding, (c) $48 \mathrm{~h}$ grinding, (d) $96 \mathrm{~h}$ grinding 
その結果，粉砕試料の方がいずれのC 添加量の場合 でも小さな值を示し，C含有量不足のために粉砕試料 のち密化が劣ったのではないことが明らかとなった。ま た, C 添加量の増加につれて, 焼結体密度は低下する 傾向を示し, 過剩 $\mathrm{C}$ 量の添加はち密化を阻止する傾向 があるものと思われる。これは必要量以上のCが存在 すると, C の拡散係数が極端に小さいことより, 逆に $\mathrm{SiC}$ 同士の合体のさまたげになることが考えられよう。

\section{6 焼結体の微構造観察}

添加 B，C 量がそれぞれ0.2，2 wt％の場合， $1650^{\circ}$, $2100^{\circ} \mathrm{C}$ で焼成した破面を SEM により，同一倍率で観 察し， $1650^{\circ} \mathrm{C}$ 焼成については，図 8 (A) に，より高 倍率の例を図 8 (B) に示した。図 8 で (a), (b), (c), (d) はそれぞれ未処理, 24 時間, 48 時間, 96 時間処理 を示す。

$1650^{\circ} \mathrm{C}$ 焼成の場合, ペレット形状寸法測定では明りょ うなち密化を認めることができず, 図 8 (A) の写真か らも明白な事項は述べられない. しかし, 高倍率の図 8

(B) の例から以下の事項が考えられよう。粉砕試料は 未処理のものと比較して粒子 1 個の大きさが小さく, 粉 砕による微細化が理解される. しかし形状は丸みを帯び ている. 粉砕直後の $\mathrm{SiC}$ の形状は比較的鋭利な面を持 つ粒子が多く見られる ${ }^{16)}$. しかし $1650^{\circ} \mathrm{C}$ の加熱処理で 形状は大部分丸みを帯び, この図からも粉砕試料の表面 が活性化され, 表面原子の移動度や反応性が著しく高ま り, 前報 ${ }^{7)}$ で明らかにしたようにメカノケミカルに活性 化されたためであるとみられる. また粒子間の接合及び 合体が起きており, 一部分粒子数個が一列につながった 部分もみられる。しかし成長粒子の大きさは, 未処理と 比べてまだ微細であった。

一方，未処理粉末の場合も同様に粒子間の接合及び合 体が起きており, 出発時の平均粒径, $0.29 \mathrm{~nm}$ の粒子と $1 \mathrm{~nm}$ ぐらいの大きさの粒子とが合体し, 徐々に粒成長 していることが観察される。したがって，この図から判 断するかぎり, 焼結の初期過程においてもメ力ノケミカ ルに活性化された結果, 蓄積されたエネルギ一はち密化 に寄与する可能性は薄いものと考えられる.

一般にち密化を伴わない焼結現象による微構造変化は 表面拡散, 蒸発, 凝縮, あるいはこれらの複合機構で進

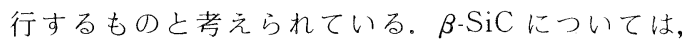
Greskovich ら ${ }^{151}$ 及び, 長谷ら ${ }^{13)}$ が提案しているように 表面拡散機構が比較的低温から支配的な役割を演じ，特 にメカノケミカル活性化処理により,なお一層より低温 領域においても表面拡散のみが助長されるものと考えら れる.このように表面拡散のみが助長された結果, 粒子 形状の丸み化 (球状化)をもたらし, その過程において, メカノケミカルに与えられたひずみエネルギーが緩和さ れてしまい，合体による粒子の接合や粗大化が進行する
が，高温でち密化に役立つ体積拡散が盛んになったとき には，意図的に付与された内部蓄積エネルギーは消滅し ており，ち密化には寄与しないと判断されよう。しかし， この考えも， $\mathrm{SiC}$ のよな共有結合性化合物において 言えることであり, Johnson ${ }^{17)}$ 及び Moriyoshi ら ${ }^{18)}$ が報 告しているように金属や一部の酸化物の焼結において, 表面拡散と粒界あるいは体積拡散の複合した機構により 初期焼結が進行するような化合物では，メカノケミカル 活性化処理がち密化に効果を及ぼす可能性も否定できな w.

最高密度の得られた $2100^{\circ} \mathrm{C}$ 焼結体の破面観察では, 粉砕試料の方が末処理のものより気孔率も高く, ち密化 が劣っていたことが分かる. 更に粉砕試料の場合, 板状 結晶が成長しており，この板状結晶が互いに絡みあって ち密化を阻害したことがうなづける。また，この板状結 晶は焼結温度が高くなるにつれて成長しやすくなり，異 常粒成長の原因になると思われる.

いずれにしても， $\beta$ - $\mathrm{SiC}$ の焼結においては, 低温領域 における表面拡散を抑制し，できるだけ内部蓄積エネル ギーが体積拡散に寄与するようにもつて行くことが高ち 密化を達成できる鍵であると考えられる。

\section{4. 総 括}

著者は振動ボールミルによる強制的な微粉砕処理によ り， $\mathrm{SiC}$ 粉末の活性を向上させることを行ってきた。 活性向上の諸因子亡しては格子久陥の導入, 格子不整の 増大, 比表面積の増加, 浸漬熱測定より算出される表面 エネルギーの増大等が挙げられる.

しかしながら，これらの諸因子の増大をはかっても $\mathrm{SiC}$ 粉末のち密化能向上には直接的に結びつかず, あ まり苛酷な微粉砕はち密化能に対して負の効果が発生す ることが判明した. 以下, 本論文で得られた知見を列記 すると以下のようになる。

（1）強制的に微粉砕した粉末の成形性は低下し，そ の低下傾向は粉砕時間が進むにつれて著しく加速され る。

(2) 微粉砕処理により誘起されたメ力ノケミカル効 果は $\mathrm{SiC}$ 粉末のち密化に寄与することがなく, 低温に おける表面拡散のみを加速するだけである。

(3) $\beta$ - SiC 原料粉末としては, 平均粒径 $0.29 \mu \mathrm{m}$, $1 \mu \mathrm{m}$ 以下の粒子含有量 $96 \%$ 程度のもので十分であり, それ以上に超微細な粒子は必ずしも必要でない。

（4）微粉砕された粉末は焼成時における質量損失が 大きく, また焼成温度が上昇するにつれて板状結晶に成 長しやすく, それが絡み合ってち密化を阻害する傾向が ある。

（5） $\mathrm{B}_{4} \mathrm{C} / \mathrm{C}$ サーモカップルにステンレス保護管を かぶせ，無機系接着剈を使って真空炉にそう入すること 
により, $2200^{\circ} \mathrm{C}$ までの真空あるいは不活性ガス中加熱 を放射温度計を使用せず，容易に行うことが可能となっ た。

結論として, 単なるボールミルでゆっくり混合し, 凝 集粒子を解砕し, 均一混合を達成させる目的のためには 有効な手段であるが，強制的な微粉砕処理はセラミック スの製造プロセスとして，あまり好ましくなく，ち密化 の観点からは適度な大きさの粒子が望まれることにな る.

付 記この研究は, 科学技術庁振興調整費による補助を 受けて行った。

\section{文献}

1) S. Prochazka, "Material Science Research, 9", Plenum Press (1975) p. 421.

2) J. A. Coppola, M. Srinivasan, K. T. Faher and R. H. S. Smoak, "Proceeding of International Symposium on Factors in Densification and Sintering of Oxide and Non-Oxide Ceramics", Tokyo Institute of Technology (1979) p. 400-17.
3) H. Tanaka and Y. Inomata, Yogyo-Kyokai-Shi, 87, 541-42 (1979).

4）田中英彦，猪股吉三，川端治雄，窯協，88，76-80 (1980).

5) A.S. Berger, V.V. Boldyrev and N.P. Kotsupalo, Dokl. Akad. Nauk SSSR, 257, 888-91 (1981).

6）管野善則, 粉体工学会誌, 22, 139-43 (1985).

7）管野善則，窯協，93，561-65（1985）。

8) "Lange's Handbook of Chemistry", 11th Edition McGraw-Hill (1973)p. 3-118.

9）管野善則, 薑協, 94, 449-51 (1986).

10) Y. Kanno, Powder Technology, 44, 93-97 (1985)

11）田中英彦，猪股吉三，佃一志，萩村 厚，窨協，92, 461-65 (1984).

12）大河内正人，安藤義則，窯協，94，36-44（1986）.

13）長谷貞三，鈴木弘茂，冨塚 功，窯協，87，317-21 (1979).

14）猪股吉三，上村揚一郎，井上善三郎，田中英彦，窯協，88， 60-65 (1980).

15) C. Greskovich and J.H. Rosolowski., J. Am. Ceram. Soc., 59, 336-43 (1976).

16）管野善則, unpublished data

17) D. L. Johnson, J. Appl. Phys., 40, 192-200 (1969).

18) Y. Moriyoshi and W. Komatsu, Yogyo-Kyokai-Shi, 81, 102-07 (1973). 